Volume 9, No.3, May - June 2020

International Journal of Advanced Trends in Computer Science and Engineering

Available Online at http://www.warse.org/IJATCSE/static/pdf/file/ijatcse12932020.pdf

https://doi.org/10.30534/ijatcse/2020/12932020

\title{
Comparative analysis of Cloud Technologies
}

\author{
Olga I. Vaganova ${ }^{1}$, Zhanna V. Smirnova ${ }^{2}$, Ekaterina V. Vovk ${ }^{3}$, Anastasia A. Kapina ${ }^{4}$, Elena A. \\ Chelnokova ${ }^{5}$ \\ ${ }^{1}$ Minin Nizhny Novgorod State Pedagogical University, Nizhny Novgorod, Russia, vaganova_o@rambler.ru \\ ${ }^{2}$ Minin Nizhny Novgorod State Pedagogical University, Nizhny Novgorod, Russia, \\ z.v.smirnova@mininuniver.ru \\ ${ }^{3}$ V.I. Vernadsky Crimean Federal University, Simferopol, Russia, ekaterina.tnu@ mail.ru \\ ${ }^{4}$ Gzhel State University, Moscow region, Ramensky District, the village of Electroizolyator, Russia, \\ anastasia.kapina@mail.ru \\ ${ }^{5}$ Minin Nizhny Novgorod State Pedagogical University, Nizhny Novgorod, Russia, chelnelena@ gmail.com
}

\begin{abstract}
Today, there is a large number of cloud technologies that are used in economic industries, business processes, and other areas of human life. Cloud technologies occupy an important place in the life of society. The purpose of the article is a comparative analysis of the capabilities of cloud technologies. The article presents a look at the platforms and cloud storage implemented by users in their professional activities and their role in the life of society. Cloud technology, including Microsoft Live@edu, Google Apps Education Edition, "DropBox", "Yandex.Disk" "Google. Disk" allows you to use applications that provide a high level of customer service. Implementing cloud tools can improve the reliability and security of any process.
\end{abstract}

Key words: cloud environment, cloud technologies, cloud computing, cloud data warehouse, electronic platform.

\section{INTRODUCTION}

The introduction of innovative technologies in the educational process is happening at a high speed. Today, they are being transformed and developed, both for economic reasons and due to changes in approaches to information technologies [1]. Software products have certain quality attributes that cannot be attributed to direct functional requirements but have a significant impact on the behavior of the system [2]. This process is always accompanied by several issues, which include purchasing, configuring and maintaining software parts, updating software, and sometimes rebuilding the entire electronic control of remote technologies [3]. To organize e-learning, it is necessary to combine the capabilities of simultaneous management of the educational process and quality control of the formation of student competence [4]. The educational institution, when choosing the most effective innovative tool, relies on the corresponding requirements that a particular tool must meet:
- functionality [5];

- stability (the level of stability under different loads depending on user activity);

- price (the user pays money only for what was used by them, not for the entire service).

- security;

- performance;

-stability;

- maintainability.

Cloud technologies meet established requirements [6]. Currently, almost every major educational institution uses cloud-based products [7].

Theoretically, the computing power of clouds is not limited [8]. Their peculiarity is that clouds allow not only to accumulate intermediate information, but also to manage a global system of computing resources [9]. In other words, the essence of cloud technologies is to provide remote access to computing resources and applications via the Internet to hosting users (users of equipment placement services on the provider's territory) [10].

In this article, we consider the possibilities of electronic educational platforms such as Moodle and WebTutor. We also analyze cloud computing service models.

Cloud platforms are software and hardware for developing and testing applications.

\section{THEPRETICAL FRAMEWORK}

Cloud computing (cloud computing) or cloud data processing provides subjects of the educational process with computer resources and capacities in the form of Internet service. Cloud computing is considered as a remote Internet space for storing and accessing data and for performing various calculations. Cloud technologies provide secure remote data storage. The development of educational content and its distribution on the Internet is carried out using various platforms [11].

Cloud hardware and software infrastructure are organized using data centers. Depending on how you access cloud services, how you work, and which data center the 
Olga I. Vaganova et al., International Journal of Advanced Trends in Computer Science and Engineering, 9(3), May - June 2020, 2563 - 2566

infrastructure belongs to, you can identify the following cloud deployment models: Private Cloud, Community Cloud, Hybrid Cloud, and Public Cloud.

Scientists note that cloud technologies open up great prospects for professional education [12]. This includes creating virtual laboratories, conducting online conferences, webinars, and managing the educational space of higher education institutions [13]. Cloud computing not only contributes to an active process of interaction between teachers and students, but also makes the following processes available:

- exchange of electronic messages, files [14];

- organization of scientific conferences with representatives of various regions [15];

- electronic submission of educational materials [16];

- conducting tests [17];

- timely informing, advising students and applicants [18].

This is not an exhaustive list of features provided by cloud technologies that researchers highlight.

Important characteristics of cloud applications are their availability on the Internet and via web applications [19].

In the organization of modern education, higher education institutions use knowledge-based networks (a set of network educational technologies and cloud services that contribute to improving the quality of education by implementing an algorithm for solving inventive tasks in the field of e-learning). This goal is achieved using an electronic remote resource-a cloud that interacts with a set of electronic educational courses. The results of the training are recorded in the form of electronic documents [20]. The knowledge network implemented on a cloud platform includes: data center for e-learning courses, cloud-a collective resource; applications for e-learning, including on "Android"; hardware and software resources for face-to-face classes.

Among the deployment models of cloud computing it is possible to allocate:

- Private Cloud (this infrastructure is designed for cloud computing within a single educational organization, with the ability to be managed and operated by a third party). This can be a cloud resource that provides various services for students of the same educational institution, for example, an electronic library for distance learning. At the same time, we note that electronic libraries of different higher educational institutions can be combined into a common resource. This increases productivity by scaling and increasing elasticity;

- Community Cloud (cloud infrastructure that can be used by a specific community of consumers from organizations that solve common tasks and share common problems);

- Public Cloud (intended for a wide range of users);

- Hybrid Cloud (a combination of two or more infrastructures. There is, for example, to use public cloud resources to maintain load balance between clouds).

Different types of cloud technologies are distinguished and used.

For example, IaaS-infrastructure as a service (users can use basic computing resources). This type of cloud technology is implemented by Amazon EC2. PaaS-platform as a service (users can install their applications on the platform that is the provider). Users control not only the choice of hardware platforms but also specific software. As an example, Google Apps Engine is a service for users to develop and install applications using the Python language.

SaaS-software as a service. This type of cloud technology is most preferable for educational institutions. You only need a network browser to do this. An example is Microsoft Live@edu and cloud services based on it. Microsoft Live@edu introduces cloud services such as:

- email;

- calendar;

- web conferences;

- ability to use virtual boards;

- editing Word, Excel, and other documents. Also, Microsoft Live@edu provides the ability to use the free cloud storage of SkyDrive files.

The Google Apps education Edition cloud platform provides the following tools for teachers and students:

- ability to use Gmail email with voice, text and video chat;

- ability to use Google disk storage of files and configure access rights to them;

- use the tool to create Google Docs documents, tables, and presentations;

- Google sites (creating sites using templates);

- Google Apps is used for information management.

Cloud technologies also allow you to develop current test tasks [21]. OpenTest is one of the tools with a simple interface consisting of several tabs. After filling in the appropriate fields with personal data, restrictions on the number of attempts, time in minutes, the order of completion of the task and summing up the results, the teacher forms a test.

To date, there are several common cloud storage systems used in the educational process [22]. Cloud storage can hold as much information as the consumer needs [23]. However, some types of storage charge a fee for additional data storage [24]. The significance of any storage is that using the cloud, the user does not need to purchase their infrastructure for storing materials [25]. The provider is responsible for the status, security, and availability of data stored in the cloud. Storage can be object-based, file-based, or block-based [26]. Object storage is mainly used for developing modern applications or for copying and archiving data [27]. File storage is provided for large content repositories and development environments. Block stores are used for each virtual server [28].

One of the most popular storage sites today is "DropBox" - a file hosting service that anchors personal cloud storage. Provides secure centralized storage of various files, from photos to video files, CAD files.

File syncing is provided from all types of devices. Another popular cloud is considered "Google.Disk». It provides storage of files of any format. Each Google account is provided with 15 free gigabytes of memory. Files can be opened from any user-friendly device. 
It should also be noted as "Yandex.Disk». It provides automatic upload of photos and videos taken on your phone. Free storage up to $10 \mathrm{~GB}$.

\section{RESULTS AND DISCUSSION}

Various electronic platforms are used to organize e-learning in higher education institutions in Russia. As part of the study, we conducted a survey among teachers of higher education institutions in the country, which allowed us to identify the platforms often used by teachers.

Figure 1 shows the results of the survey.

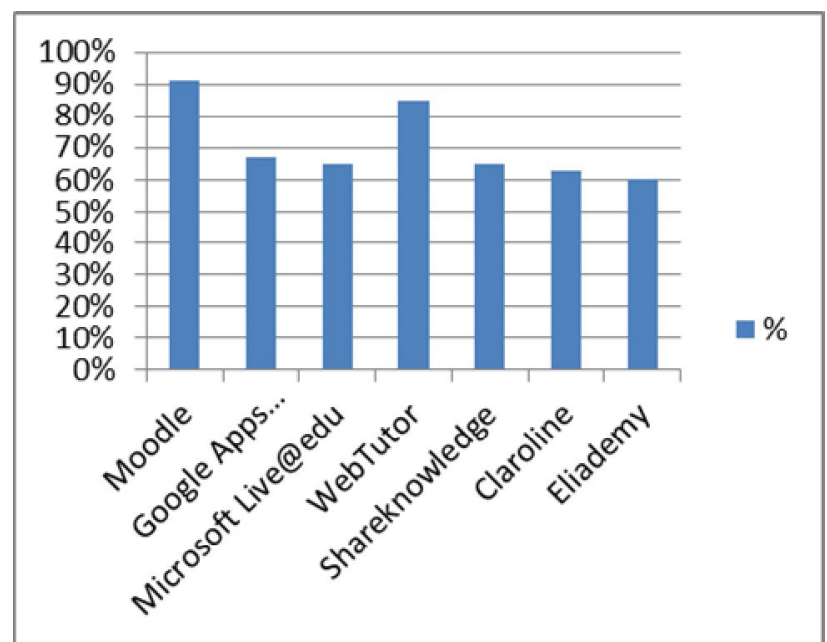

Figure 1: Results of data processing of teachers' choice of electronic platforms for organizing e-learning

Two platforms - Moodle and WebTutor-received the greatest advantage. We have shown these platforms in table 1 and compared them.

Table 1: Comparative characteristics of electronic platforms

\begin{tabular}{|l|l|l|}
\hline \multirow{2}{*}{ Function } & \multicolumn{2}{|c|}{ Platform } \\
\cline { 2 - 3 } & Moodle & Webtutor \\
\hline Accounting for each student & + & + \\
\hline $\begin{array}{l}\text { Ability to develop and } \\
\text { implement online courses }\end{array}$ & + & + \\
\hline $\begin{array}{l}\text { Reporting on statistics and } \\
\text { training }\end{array}$ & + & + \\
\hline $\begin{array}{l}\text { Ability to create tests, surveys, } \\
\text { questionnaires }\end{array}$ & + & - \\
\hline $\begin{array}{l}\text { Possibility of timely monitoring } \\
\text { and assessment of knowledge }\end{array}$ & + & + \\
\hline $\begin{array}{l}\text { Ability to combine with other } \\
\text { information systems }\end{array}$ & + & - \\
\hline Cost & + & + \\
\hline
\end{tabular}

Moodle provides users with more opportunities, but WebTutor is second only on two points out of seven. WebTutor does not offer the ability to create questionnaires and questionnaires, as well as integration with other information systems. The idea of developing Moodle belongs to Australian specialists. This platform is one of the most popular in the world, including in Russia. According to the research, it is chosen by the majority of Russian higher education institutions. Its advantage over other platforms is that it is free of charge (payment is made only for additional services and storage space for files), and that it can be downloaded freely on the Internet. WebTutor was developed by Russian programmers - software manufacturer WebSoft. It allows you to organize and store training information, allows you to organize communication and interaction between the subjects of the educational process.

\section{CONCLUSION}

Cloud technologies provide broad opportunities for education, business, and the country's economy as a whole. Soon, the development of cloud technologies as a service (SaaS, PaaS, Iaas), as data storage, for example, "DropBox", " Yandex. Disk" "Google. Disk" will be associated with the introduction of machine learning systems, such as artificial intelligence or augmented reality.

Modern higher education institutions adopt each other's experience, exchange relevant information and develop cooperation to improve the effectiveness of e-education using cloud technologies. The practice of educational institutions reflects the process of overcoming the difficulties of implementing cloud technologies in the educational process. The role of cloud technologies in e-education is quite high. Cloud technologies allow the user to choose the necessary number of resources to work with. At the same time, all the services that the cloud allows you to use are available to every subject of the educational process at any time, in any place, regardless of the platform used. Cloud technologies provide convenient scalability of resources to reduce or increase power consumption. The cloud technologies implemented by modern Russian higher education institutions make it possible to activate the learning process and make it more mobile.

Comparative analysis allows you to optimize the process of selecting these services for organizing educational and business processes and improving other areas of society. Through comparative analysis, we can identify the most promising areas of cloud technologies that will be in demand in the near future.

\section{REFERENCES}

1. Pliushch, V.M. (2018). Independent work of students as a factor of improving education quality. Balkan Scientific Review, 1, 69-71.

2. Aleksieienko-Lemovska, L.V. (2019). The activity approach as a basis for preschool teachers' methodological activities, Humanitarian Balkan Research, 3, 4(6), 10-14.

3. Ilyashenko, L. K., Smirnova, Zh. V., Vaganova, O. I. Chelnokova, E. A., Kaznacheeva, S.N. (2019). Methods of Conducting Practical Training on the Subject "Power Sources for Welding", International Journal of 
Olga I. Vaganova et al., International Journal of Advanced Trends in Computer Science and Engineering, 9(3), May - June 2020, 2563 - 2566

Mechanical Engineering and Technology, 10 (02), 908-917.

4. Andriushchenko, T. K., (2018). Personal aspects of pedagogue's innovative culture, Scientific Vector of the Balkans, 1, 13-16.

5. Bakharev, N. P., (2019). Creativity - a prerequisite for the formation of professional competences in specialists of technical direction of training, Scientific Vector of the Balkans, 3, 4 (6), 17-21.

6. Cirdan, A.P. (2019). Innovative technologies of professional training of future economists in the system of continuous education. Humanitarian Balkan Research, 2(4), 27-30.

7. Filchenkova, I.F. (2019). Educational management of innovative activity of teachers as an object of pedagogical research. Vestnik Mininskogo universiteta (Vestnik of Minin University), 2019. 7 (4), 3. (in Russ.).

https://doi.org/10.26795/2307-1281-2019-7-4-3

8. Myalkina, E.V. (2019). Diagnostics of the education quality in the higher educational institution. Vestnik Mininskogo universiteta (Vestnik of Minin University), 7, (3), 4. (in Russ.) https://doi.org/10.26795/2307-1281-2019-7-3-4

9. Oros, I.I. (2018) The role of international connections in the development of the adult education system. Humanitarian Balkan Research, 1, 57-59.

10. Osadchenko, I.I. (2019). Key concepts of situational training technology in preparing future teachers. Scientific Vector of the Balkans, 1 (3), 46-49.

11. Pichugina, G.A., Bondarchuk, A.I. (2019a). Structure of the training case in the organization of the educational process. Humanitarian Balkan Research, 2(4), 5-7.

12. Pichugina G. A., Zhilyakova D. A. (2019b). Structuring the organization of the process of creativity. Scientific Vector of the Balkans, 3, 3 (5), 55-58.

13. Halatsyn, K.A., Feshchuk, A.M. (2019). Diagnosing motivational-and-valuable component of the communicative culture of students in higher technical educational institutions, Balkan Scientific Review, 3, 2 (4), 17-20.

14. Pisarenko, D. A. (2019). Evaluation of extracurricular activities of university students with a competency-based approach, Scientific Vector of the Balkans, 3, 3 (5), 37-40.

15. Vaganova, O.I., Rudenko, I.V., Markova, S.M., Smirnova, Zh.V., Kutepov, M.M. (2019b). The use of educational video materials in educational process of a higher educational institution. Amazonia Investiga, 8 (22), 216-222.

16. Grigoriev S. G., Shabunina V. A., Tsarapkina Ju. M., Dunaeva N. V. Electronic library system as a means of self-development of students of digital generation $\mathbf{Z}$ (on the example of studying the course "Basics of the counselor activity"). Scientific and technical libraries. 2019. No. 7. Pp. 78-99. 29. https://doi.org/10.33186/1027-3689-2019-7-78-99

17. Andrienko, O.A. (2019). Network educational technologies and their use when working with students. Humanitarian Balkan Research 2019, 1(3), 5-7.

18. Koshechko, N.V. (2018). Innovations from educational discipline "Pedagogical conflictology" in professional preparation of students. Scientific Vector of the Balkans, 1, 59-63.

19. Chirva, A.N., Chirva, O.G. (2018). Contents and method of professionally oriented training of informatic disciplines of future teachers of technologies. Scientific Vector of the Balkans, 1, 27-31.

20. Kamenez, N.V., Smirnova, Zh. V., Vaganova, O. I., Bystrova, N.V., Tsarapkina, J.M., (2019). Development of Instructing Techniques in Professional Training, International Journal of Mechanical Engineering and Technology, 10(02), 899-907.

21. Andrienko, O.A. (2019). On the need to apply gaming training technologies. Balkan Scientific Review, 2 (4), 5-8.

22. Klinkov, G.T. (2018). The specificity of manifestation of pedagogical communication as a special construct. Scientific Vector of the Balkans, 1, 51-52.

23. Vaskovskaya, G.A. (2018). Features of implementation of pedagogical technologies of profile training. Balkan Scientific Review, 1, 76-79.

24. Vinothini K., Aida M., Heng C. Y., (2019). CodeCube: Active Learning for STEM, International Journal of Advanced Trends in Computer Science and Engineering, 8 (1.3), 293-299. https://doi.org/10.30534/ijatcse/2019/5581.32019

25. Syamsul, B. Z., Emram, Y., (2019). Perceptions of Computational Thinking in Game Based Learning for Improving Student Problem Solving Skills, International Journal of Advanced Trends in Computer Science and Engineering, 8 (1.3), 181-184. https://doi.org/10.30534/ijatcse/2019/3681.32019

26. Irwan, M. I., Siti, K., Anis, Mohd, E. I. Kamaruzzaman, I., Norazah, M. N. (2019). Impact of Games on Motivation, Attention and Skills in Pre-school Children, International Journal of Advanced Trends in Computer Science and Engineering, (2019), 8 (1.3), 157-159. https://doi.org/10.30534/ijatcse/2019/3181.32019

27. Tsarapkina, Ju.M., Petrova, M.M., Mironov, A.G., Morozova, I.M., Shustova, O.B. (2019a). Robotics as a basis for Informatization of education in children's health camp. Amazonia Investiga, 8 (20).

28. Vaganova, O.I., Ilyashenko, L.I., Smirnova, Zh.V., Bystrova, N.V., Kaznacheeva, S.N. (2019a). Students' creative abilities development in higher educational institution. Amazonia Investiga, 8 (22), 701-710 